\title{
GERABAH SITI KENCONO AJI DI DESA PANJANGREJO PUNDONG BANTUL
}

\author{
Indro Baskoro \& Arif Suharson
}

\begin{abstract}
ABSTRAK
Kelompok pengrajin gerabah Siti Kencono Aji adalah salah satu kelompok pengrajin gerabah yang ada Desa Panjangrejo. Kelompok pengrajin ini didirikan sebagai wahana kegiatan bersama untuk meningkatkan kesejahteraan kelompok pada khususnya dan kesejahteraan masyarakat pengrajin gerabah di Desa Panjangrejo pada umumnya. Hasil produk gerabah biasanya berwujud souvenir yang pada umumnya dipasarkan dalam bentuk merahan dan hanya berdasarkan pesanan. Sebagian besar masyarakat pengrajin gerabah di Panjangrejo belum mengoptimalkan diri untuk membuat desain-desain baru ataupun mengaplikasikan teknologi finishing pada produk gerabahnya. Belum lagi system pengelolaan usaha dan manajemen yang masih seadanya, sehingga hasil produksi gerabah yang dikerjakan oleh pengrajin Panjangrejo belum dapat berkembang dengan baik.

Kegiatan meningkatkan mutu produksi terutama dalam menciptakan desain-desain baru dan finishing produk, teknik pewarnaan dengan warna cat dan aplikasi bahan lain yang ada di sekitar pengrajin menjadi solusi tepat agar gerabah Panjangrejo memiliki ciri khas. Sistem manajemen usaha dan pemasaran juga menjadi target program pendampingan agar kelompok masyarakat pengrajin gerabah di Desa Panjangrejo mampu mengelola dan mengembangkan usaha gerabahnya. Sehingga dengan program ini, masyarakat pengrajin gerabah Desa Panjangrejo akan menjadi maju dalam usaha gerabah dan meningkat taraf ekonominya yang didukung dengan pengeloaan usaha/ manajemen yang baik.

Program ipteks bagi masyarakat (IbM) diharapakan mampu membantu permasalahan mitra dalam hal inovasi dan finishing produk gerabah di Desa Panjangrejo. Pengembangan desain diarahkan agar gerabah produksi masyarakat Panjangrejo tidak monoton berbentuk silindris, tetapi memiliki diversifikasi bentuk, dan lebih mengarah pada perbaikan mutu produk agar mampu menembus pasar global, sehingga meningkatkan ekonomi masyarakat pengrajin gerabah Panjangrejo. Pelatihan manajemen dan pemasaran e-commerce melalui media on line juga menjadi sasaran program pemberdayaan masyarakat, agar pemasaran produk gerabahnya dapat menjangkau pasar yang lebih luas secara nasional maupun internasional.
\end{abstract}

Kata Kunci: Gerabah, Panjangrejo Pundong, Desain, Finishing

\section{PENDAHULUAN}

Kabupaten Bantul banyak memiliki potensi sentra industri kreatif dimana hasil seni kreatifitas kerajinannya mampu menghidupi dan menjadi sumber penghidupan bagi masyarakat yang menggeluti bidang kerajinan tersebut. Bahkan beberapa hasil seni kerajinan dari Kabupaten Bantul telah banyak yang dijual sampai ke mancanegara menembus pasar eksport. Hal ini membuktikan bahwa hasil produk seni kerajinan di Kabupaten Bantul

*) Indro Baskoro, Arif Suharson (arifkeramos@yahoo.com), Staf Pengajar Program studi Kriya Seni, Jurusan Kriya, Fakultas Seni Rupa, Institut Seni Indonesia Yogyakarta. 
memiliki kualitas unggul dan mampu memenuhi kuantitas produk yang diinginkan pasar industri kreatif.

Salah satu potensi keunggulan itu dibuat dari bahan gerabah yang memberikan dampak perekonomian bagi masyarakat, seperti yang ada di wilayah Desa Kasongan yang juga telah menjadi desa wisata. Karena status yang melekat sebagai desa wisata ini, Kasongan dikenal sebagai wilayah penghasil gerabah yang memiliki ciri khas dan menjadi tempat para pelancong bahkan buyer seni kerajinan untuk membeli hasil kerajinan gerabah tersebut.

Selain Desa Kasongan, Kabupaten Bantul juga memiliki Desa Panjangrejo Pundong Bantul yang juga menyuplai kebutuhan produk gerabah dan memenuhi pesanan produk gerabah yang berukuran kecil yang tidak mampu dibuat oleh pengrajin gerabah di Desa Kasongan. Dapat dikatakan bahwa kebutuhan gerabah yang sifatnya berukuran kecil atau yang dikenal dengan gerabah souveniran dibuat oleh masyarakat Panjangrejo Pundong. Tetapi sifatnya hanya mentah/abangan di dalam ilmu keramik disebut produk bisquit. Produk ini baru dibakar satu kali dengan suhu berkisar antara $600-900^{\circ} \mathrm{C}$ dan biasanya warnanya merah, kuning kemerahan, atau merah bata.

Produk setengah jadi dari Desa Panjangrejo yang bersifat abangan belum difinishing, kemudian disetorkan ke pemesan yaitu masyarakat Desa Kasongan yang oleh masyarakat Desa Kasongan produk abangan tadi diberi finishing cat. Terjadi jalinan kerjasama yang baik, walaupun terkadang keuntungan yang didapat tidak seimbang karena lokasi Desa
Kasongan yang lebih dahulu menjadi pusat destinasi wisata yang maju. Sehingga daerah ini menjadi daerah potensial untuk menjual produk gerabah karena banyaknya tamu yang berkunjung, baik dari dalam kota atau luar kota yang ingin mengetahui proses produksi atau memang sengaja ingin membeli produk gerabah untuk souvenir atau hiasan interior dan eksterior ruangan.

Keadaan yang berlangsung ini membuat para pelaku pengrajin gerabah Panjangrejo amat tergantung dengan pesanan dan hanya melayani gerabah yang sifatnya abangan yang dianggap praktis dan tidak ribet karena harus memberikan finshing dalam produk gerabahnya. Pandangan bahwa membuat finishing itu susah dan lama membuat daya kreasi gerabahnya monoton. Dan kalaupun ada pesanan bentuk yang baru biasanya proses pembuatan awalnya sangat lama dan cenderung untuk menolak dan kalau bisa mengerjakan produk yang sudah seperti biasanya dibuat. Terlebih lagi jika produknya berbentuk non silindris dan ukurannya agak besar.

Teknik putar handwheel yang biasa dilakukan menjadi alasan utama bahwa irama pembuatan produk silindris yang cepat dan mudah sering menjadi alasan utama untuk mengembangkan produk dengan desain-desain baru yang lebih variatif. Pola pikir inilah yang coba dirubah dan diberikan pendampingan melalui program IbM agar beberapa masyarakat yang mau berubah kita ajak untuk melakukan pengembangan desain-desain baru, mencoba membuat diversifikasi produk dan melakukan finishing touch agar produk gerabah Panjangrejo meningkat harga jualnya. Hal ini tentu akan 
meningkatkan nilai ekonomi masyarakat dengan melakukan inovasi produk dan teknik pemasaran yang berbeda tidak tergantung pasar yang ada di Desa Kasongan. Tetapi dapat menciptakan pasar sendiri yang membawa keuntungan dan Desa Panjangrejo dapat menjadi desa wisata gerabah yang dapat dikembangkan menjadi destinasi wisata gerabah di Kabupaten Bantul selain Desa Kasongan.

\section{HASIL DAN PEMBAHASAN}

Desa Panjangrejo Pundong Bantul memiliki kelompok pengrajin yang tergabung dalam wadah Kelompok pengrajin yang bernama Siti Kencono Aji. Selama ini Kelompok Siti Kencono Aji telah aktif menampung dan menggerakkan pengrajin gerabah agar mampu mendukung kebijakan pengembangan kepariwisataan di Desa Panjangrejo Kecamatan Pundong, Kabupaten Bantul. Kelompok pengrajin ini didirikan sebagai wahana kegiatan bersama untuk meningkatkan kesejahteraan kelompok pada khususnya dan kesejahteraan masyarakat pengrajin gerabah di Desa Panjangrejo pada umumnya.

Gerabah yang diproduksi oleh masyarakat Desa Panjangrejo juga dikenal dengan sebutan gerabah atau keramik Pundong. Bahan yang digunakan sebagai bahan baku adalalah tanah liat yang diambil dari daerah Godean, Sleman dengan dikombinasikan dengan tanah dari daerah Mangunan, Bantul yang diproses dengan mesin giling. Pembuatan gerabah dilakukan dengan teknik putar tangan atau hand wheel. Gerabah Panjangrejo kebanyakan diproduksi berdasarkan atas pesanan dari sentra gerabah yang ada di
Desa Kasongan. Kasongan menjadi salah satu tempat penjualan gerabah dari Panjangrejo melalui perantara pedagang Kasongan yang memiliki showroom di desa wisata tersebut. Akan tetapi gerabah yang dipasarkan masih berupa barang setengah jadi dalam bentuk merahan yang belum melalui proses finishing. Sehingga harga jual produk rendah dan keuntungan yang diperoleh masyarakat pengrajin gerabah dari Desa Panjangrejopun menjadi lebih rendah.

Menurut informasi dalam satu diskusi dengan Ketua kelompok Siti Kencono Aji (Sunardi, 40 tahun, wawancara 3 Juli 2015) diperoleh keterangan bahwa hasil gerabah masyarakat Panjangrejo belum bisa memenuhi keinginan konsumen, terutama produk gerabah dengan desain baru dan berukuran besar. Masyarakat Desa Panjangrejo terbiasa memproduksi gerabah berukuran kecil yang terkenal dengan sebutan gerabah souvenir. Produk gerabah souvenir umumnya juga dipasarkan dalam bentuk merahan dan hanya berdasarkan pesanan. Masyarakat pengrajin belum memiliki keberanian untuk membuat desain-desain baru ataupun mengaplikasikan teknologi finishing pada produk gerabahnya. Memang sudah ada beberapa pengrajin yang sudah melakukan terobosan membuat diversifikasi produk, akan tetapi belum maksimal.

Tidak mengherankan, dengan keuntungan yang kecil membuat gerabah masih menjadi pekerjaan sampingan dan belum menjadi usaha yang benar-benar ditekuni oleh sebagian masyarakat pengrajin. Permasalahan tersebut terjadi karena sumber daya manusia yang dapat 
melakukan inovasi produk dan memadukan finishing produk dengan warna cat atau finishing dengan aplikasi bahan lain yang diinginkan konsumen sangat terbatas. Belum lagi system pengelolaan usaha dan manajemen yang masih seadanya, sehingga hasil produksi gerabah yang dikerjakan oleh pengrajin Panjangrejo belum dapat berkembang dengan baik.

Langkah konkret dilakukan dengan melakukan program IbM yaitu dengan beberapa solusi yang tepat. Mampu membantu permasalahan mitra dalam hal inovasi dan finishing produk gerabah di Desa Panjangrejo. Pengembangan desain diarahkan agar gerabah produksi masyarakat Panjangrejo tidak monoton berbentuk silindris, tetapi memiliki diversifikasi bentuk, dan lebih mengarah pada perbaikan mutu produk agar mampu menembus pasar keluar daerah sehingga meningkatkan ekonomi masyarakat pengrajin gerabah Panjangrejo.

Untuk meningkatkan kemampuan desain gerabah sehingga tercipta produk gerabah yang inovatif dan berkualitas, dilakukan dengan beberapa cara berikut :
a. Pembinaan, pelatihan, dan pendampingan membuat inovasi pengembangan desain produk gerabah di Desa Panjangrejo.

b. Penerapan teknologi tepat guna yang relevan, yaitu finishing produk dengan bahan cat dan aplikasi bahan lain yang terdapat disekitar tempat tinggal pengrajin gerabah
c. Teknologi Tepat Guna dengan memberikan pelatihan cetak reproduksi dengan bahan gypsum

d. Pendampingan pemasaran dengan membuatkan sistim penjualan on-line dengan membuat web kelompok pengrajin Siti Kencono Aji dengan spesifikasi produk, ukuran, dan harga yang kompetitif.

Untuk memperlancar program agar dapat menjadi panduan tim dan para pengrajin Desa Panjangrejo perlu dibuat alur kerja yang jelas agar hasil dari program IbM dapat mencapai target yang direncanakan. Hal ini juga mempermudah kerja tim dan menjadi tolok ukur keberhasilan tiap langkah-langkah yang ditempuh dan jika menemui kendala dapat segera dicari solusi yang tepat. Alaur kerja tersebut dapat dilihat dalam diagram seperti di bawah ini:

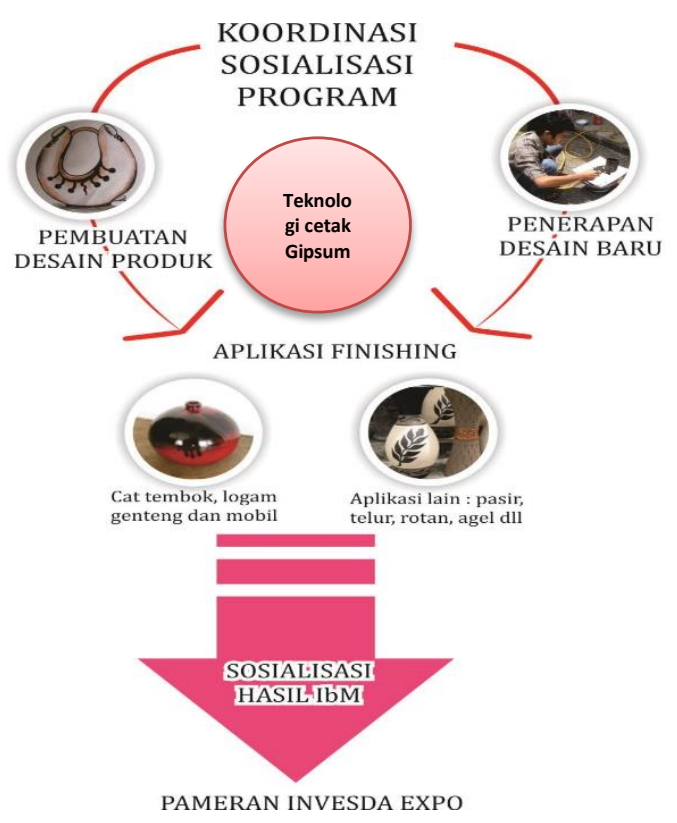

Pelaksanaan kegiatan melibatkan 15 pengrajin anggota kelompok perajin Siti Kencono Aji. Peserta dipilih dari pengrajin yang selama ini aktif menjalankan usaha kerajinan dan menjadikan kerajinan gerabah sebagai sumber pendapatan utama. Program pelatihan dibagi menjadi beberapa tahap, yaitu: 


\section{a. Pelatihan Tahap 1}

Kegiatan ini dilaksanakan pada tanggal 19 Agustus 2016. Dalam kegiatan ini, disampaikan 2 materi, yaitu : 1) Mengenali Bentuk Desain Gerabah Modern. Materi ini disampaikan oleh Indro Baskoro Miko Putro, S.Sn. Dalam materi ini peserta mendapatkan informasi dan panduan untuk merekayasa bentuk produk kerajinan gerabah modern dan fungsional. Ide bentuk desain bisa didapatkan dari berbagai sumber. Seperti mencari inspirasi dari bentuk yang ada di lingkungan sekitar; 2) Meningkatkan Pemasaran dengan Online Shop. Materi ini disampaikan oleh pengrajin berpengalaman, yaitu Okta Galih Adiputra, S.Hut. Dalam materi ini pengrajin mendapatkan pengalaman tentang kelebihan pemasaran online dan persyaratan untuk sukses dalam pemasaran. Agar mampu bertransaksi dengan buyers luar negri, pengrajin harus memiliki kemampuan untuk menjaga kualitas produk, pengrajin harus memiliki kemampuan control kualitas atau QC (Quality Control) yang memadai.

Untuk mempersiapkan peserta pada pelatihan selanjutnya, maka pada pelatihan tahap 1 setiap peserta mendapatkan tugas untuk membuat produk gerabah dengan desain bentuk baru.

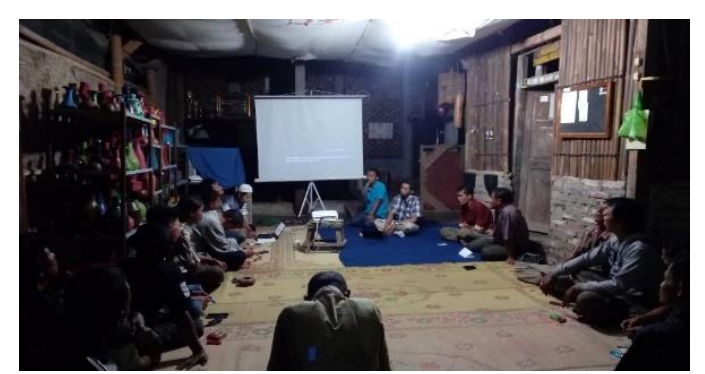

Gambar 1. Suasana Pelatihan Tahap 1

\section{b. Pelatihan Tahap 2}

Pelatihan dilaksanakan pada tanggal 9 September 2016. Dalam pelatihan ini difokuskan untuk menyampaikan materi ketrampilan inovasi produk yang mencakup sub materi tentang Mengenali Bentuk Desain Gerabah Skala Ekspor dan Trend Disain Produk yang sedang berkembang. Materi disampaikan oleh Arif Suharson, S.Sn, M.Sn - Praktek Finishing Dasar. Praktek didampingi langsung oleh 3 dosen peneliti dari ISI yaitu Arif Suharson, S.Sn., M.Sn., Indro Baskoro Miko Putro, S.Sn., dan I Made Sukanandi., S.Sn., M.Sn. Dalam kesempatan pelatihan ini, produk yang dibawa oleh peserta diproses lebih detail dengan aplikasi ketrampilan pendempulan dan finishing dasar cat putih secara halus.

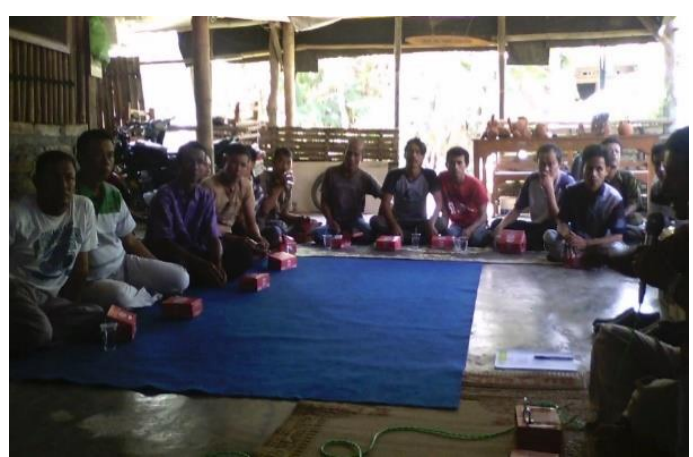

Gambar 2. Suasana Pelatihan Tahap 2

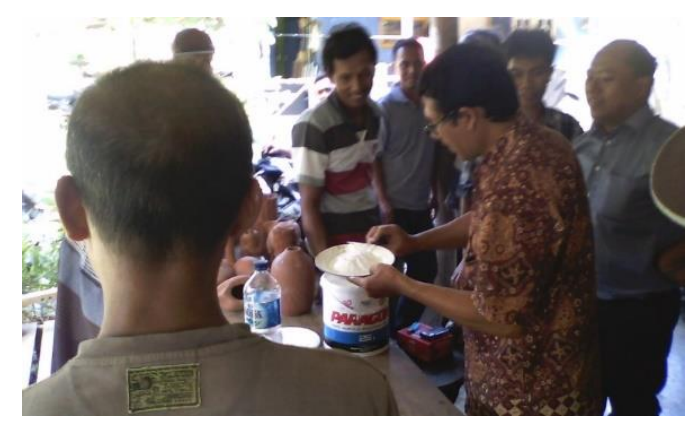

Gambar 3. Praktek pendempulan halus pada bodi gerabah oleh pengrajin 


\section{c. Pelatihan Tahap 3}

Pelatihan dilaksanakan pada tanggal 10 September 2016

Materi yang disampaikan mencakup:

- Pemaparan Peluang Pemasaran

Materi disampaikan oleh perwakilan dari Dinas Perindustrian Perdagangan dan Koperasi Kabupaten Bantul. Pemerintah dalam kesempatan tersebut menjanjikan untuk menyediakan ruang pameran untuk produk gerabah Pundong. Hanya saja ruang pamer tersebut masih dirasa kurang karena hanya akan memanfaatkan kegiatan Sekaten, dimana segmen pasar tidak sesuai dengan produk yang dihasilkan oleh gerabah Pundong.

- Praktek Finishing dengan Metode Cat Tembaga dan Lukis.

Materi disampaikan secara bergantian oleh Indro Baskoro Miko Putro, S.Sn., Arif Suharson, S.Sn., M.Sn., dan I Made Sukanandi, S.Sn., M.Sn

Dalam kesempatan ini, narasumber memperkenalkan empat metode finishing alternatif dan baru dalam dunia kerajinan gerabah yang ditemukan oleh narasumber dan diharapkan dapat menjadi ciri khas dari kerajinan gerabah Pundong, Bantul. Keempat metode tersebut adalah cat warna tembaga, lukis air, lukis batik dan lukis tumpuk garis. Keempat metode ini diharapkan mampu mendorong terciptanya produk gerabah pundong yang khas dan unik, yang tidak ditemukan dalam produk serupa dari gerabah lainnya. Dalam kesempatan tersebut juga dipilih 3 karya terbaik, yaitu karya gerabah kuning pelangi sebagai produk finishing terbaik, produk gerabah keropos sebagai produk modern terbaik dan gerabah kucing sebagai produk gerabah terunik.

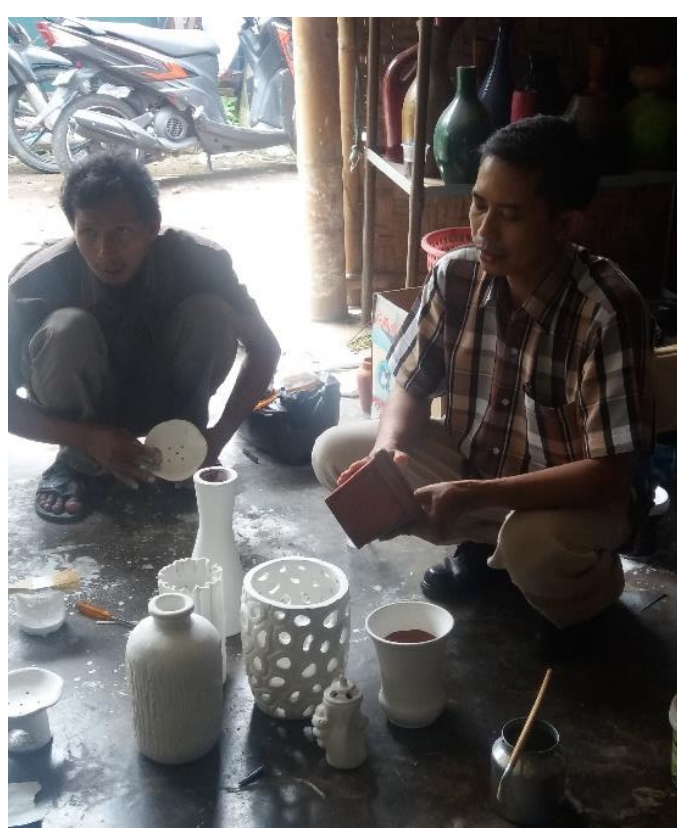

Gambar 4. Praktek Cat tembaga pada bodi gerabah.

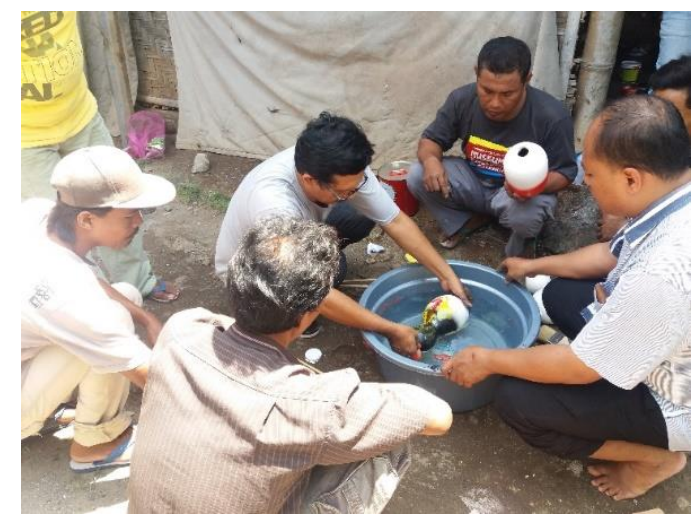

Gambar 5. Praktek Cat Lukis Air (Painting In the Water)

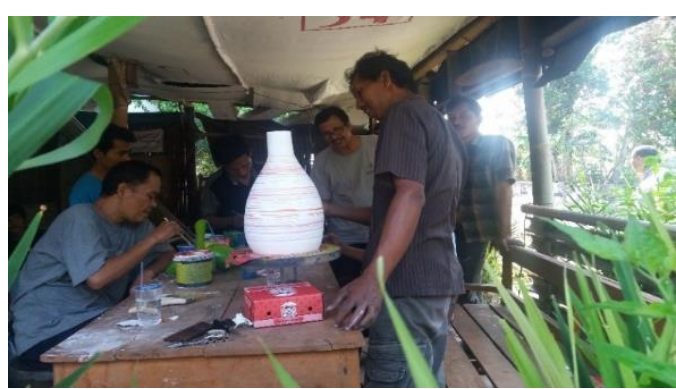

Gambar 6. Praktek Cat Tumpuk Garis Pada bodi Gerabah Silindris 


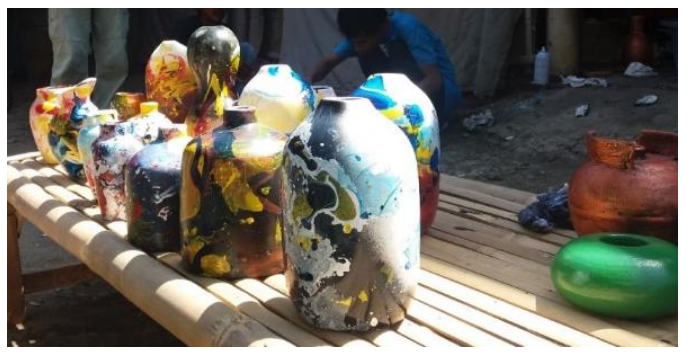

Gambar 7. Pengeringan produk hasil pelatihan

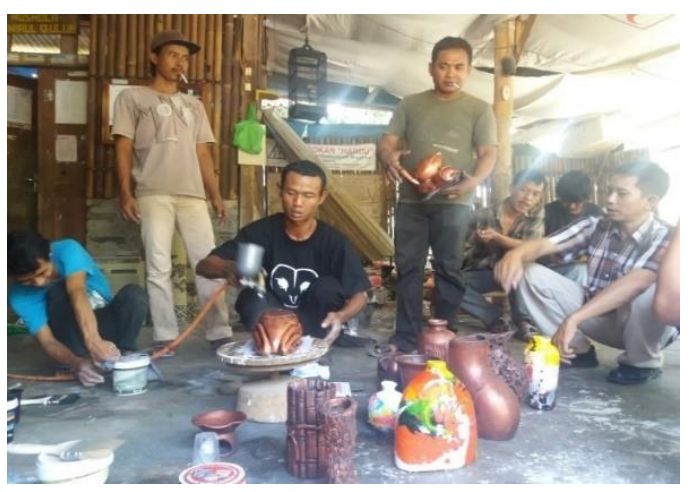

Gambar 8. Proses melamin produk yang sudah difinishing

Dari hasil pelatihan dapat terlihat nyata perubahan tampilan produk sebelum dan sesudah pelatihan. Hal tersebut tidak terlepas dari kemampuan ISI Yogyakarta dalam mentransfer keilmuan dan hasil penelitian kepada pengrajin gerabah Pundong. Mengingat selama ini pengrajin membuat produk gerabah hanya berdasarkan pengalaman yang diturunkan secara turun menurun tanpa mengetahui teori dasar dalam mengolah dan menciptakan produk gerabah.

ISI Yogyakarta melalui program IbM ini memberikan penguatan keilmuan sehingga dalam proses inovasi produk kedepan, pengrajin gerabah Pundong benar-benar melakukannya dengan tehnik yang benar dan dilandasi ilmu pengetahuan yang kuat untuk menghasilkan produk yang inovatif, khas dan unik.

Salah satu teori pengolahan produk yang diaplikasikan dan terbukti mampu mengubah penampilan gerabahn Pundong adalah tehnik finishing lukis air, lukis batik dan pewarnaan tembaga. Tehnik lukis air adalah tehnik baru yang baru diperkenalkan oleh ISI Yogyakarta dan belum diterapkan dalam pembuatan gerabah dimana pun. Sehingga dengan dapat menghasilkan produk paten khas gerabah Pundong, yang membedakannya dengan produk gerabah lain.

Selain teknologi tepat guna secara ilmu praktis produksi gerabah dalam program IbM ini juga memberikan manfaat teknis dalam hal penjualan produk yang didukung pola jiwa kewirausahaan dan manajerial usaha yang handal.. Hal ini dilakukan agar menambah potensi peluang pasar secara global dengan pelatihan manajemen dan kewirausahaan.

Pembuatan toko online dilakukan web desainer professional. Tahapan finishing telah mencapai $100 \%$ pada bulan September 2016 dan telah disosialisasikan kepada pengrajin. Tahapan dalam pembuatan toko online ini meliputi pembelian domain, pembuatan konten web, klasifikasi produk, dan pengunggahan spesifikasi produk unggulan. Produk yang diunggah adalah produk asli dari pengrajin.

Adapun informasi utama yang akan disajikan dalam website adalah:

- Nama domain yang digunakan adalah www.terakotapundong.com

- Logo yang digunakan adalah sebagai berikut : 


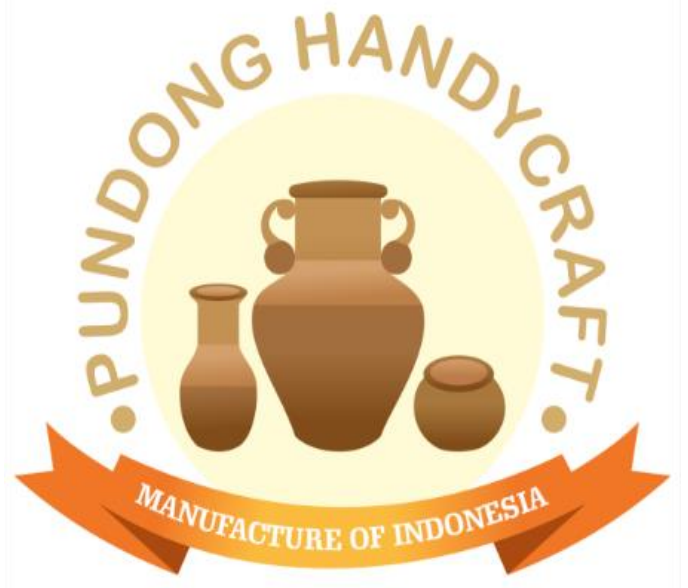

Gambar 9. Logo Sentra Handycraft Pundong

- Sekretariat pemasaran menggunakan alamat showroom kerajinan gerabah Pundong desa Panjangrejo

- Informasi yang disediakan di dalam website meliputi map sekretariat pemasaran, galeri produk, kegiatan wisata serta artikel pendukung

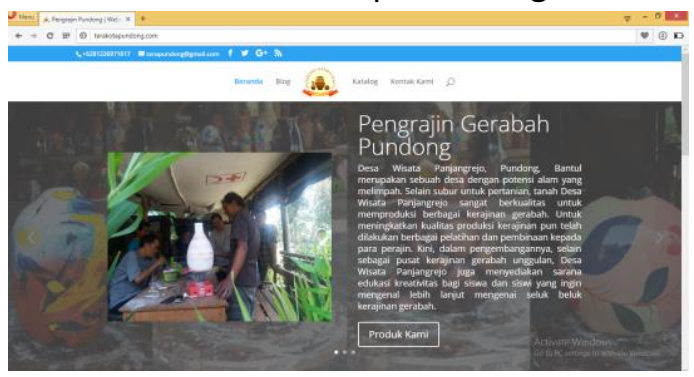

Gambar 10. Tampilan muka website: www.terakotapundong.com

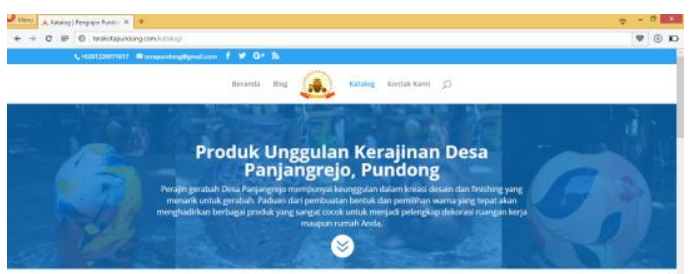
Kerajinan Gerabah Dengan Finsthing Menarik

Gambar 11. Tampilan isi katalog website: www.terakotapundong.com

\section{KESIMPULAN}

Sentra gerabah Panjangrejo Pundong Bantul menghasilkan produkproduk gerabah silindris dengan produk berukuran kecil yang sering disebut gerabah souveniran. Perkembangan dunia keramik modern menuntut bentuk diversifikasi produk dimana kebutuhan akan desaindesain produk gerabah tidak hanya berbentuk silindris. Konsumen menginginkan ada sentuhan produk yang kreatif dan inovatif selain bentuk-bentuk gerabah silindris. Bentuk-bentuk tersebut dapat ditempuh dengan membuat produk gerabah non silindris. Untuk dapat mencapai bentuk non silindris hanya dapat dilakukan dengan teknik cetak atau sering disebut teknik reproduksi keramik.

Seiring dengan pencapaian bentukbentuk non silindris kreatif dan inovatif di sentra gerabah Panjangrejo sangat dibutuhkan keahlian teknik dan bahan tanah yang digunakan. Selain itu ini juga dibutuhkan sentuhan finishing yang baik agar produk gerabah mampu laku dijual di pasar global. Finishing sangat berfungsi untuk menambah nilai estetis atau keindahan suatu produk. Selain itu juga dapat digunakan sebagai perlindungan yang menyesuaikan kegunaannya. Perlindungan melalui proses finishing tersebut mengakibatkan produk mampu menjadi lebih awet dan bisa digunakan lebih lama. Contohnya adalah finishing untuk produkproduk eksterior yang mampu memberi perlindungan terhadap cuaca seperti panas, dingin, dan hujan. Melalui program IbM ini telah dilakukan pengembangan produksi dan teknik yang mampu mmembuat diversifikasi bentuk yang baik. Juga pengenalan finishing cat pabrikasi yang 
mudah diterapkan yang akan mengangkat harga jual produk gerabah masyarakat Panjangrejo Pundong Bantul.

Finishing produk dengan media dempul pada bodi layaknya cat mobil untuk memberikan diversifikasi finishing yang berbeda sesuai dengan kemauan pasar dan disesuaikan isu trend disain yang berkembang. Finishing dengan bahan cat pabrikasi ini paling mudah dilakukan dan mudah memperoleh bahan-bahan catnya di toko-toko cat di sekitar masyarakat pengrajin. Kita dapat melakukan finishing dengan cat tembok, cat poster, cat genteng, cat mobil, dan cat-cat lain yang dapat merekat pada bodi gerabah. Keahlian dalam membuat karakter dengan cat dan ornamen pada bodi gerabah menjadi kunci keberhasilan yang mampu mengangkat harga jual produk. Yang demikian akan mampu meningkatkan taraf hidup masyarakat pelaku pengrajin gerabah di Panjangrejo Pundong Bantul dengan meningkatnya daya kreasi cipta inovatif pengrajinnya.

\section{CONTOH PRODUK HASIL IbM}

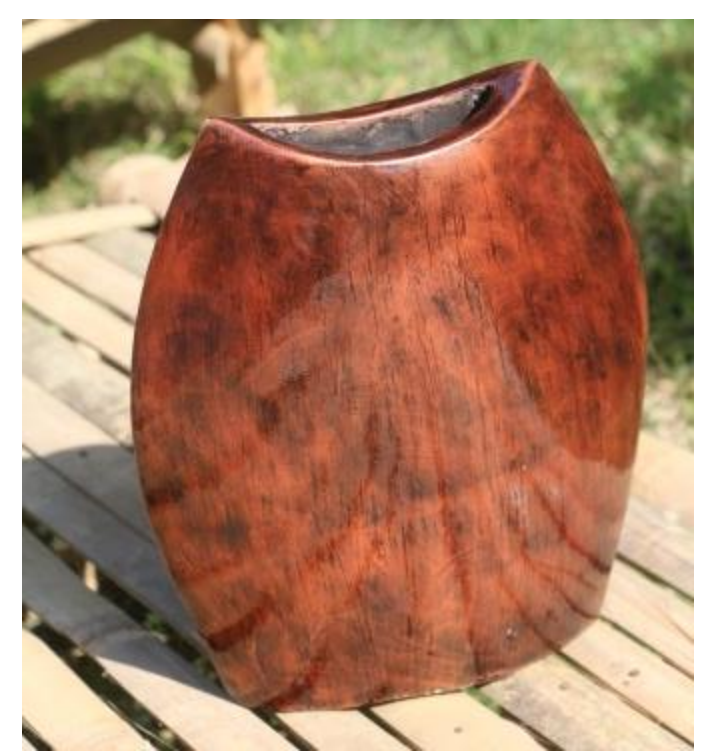

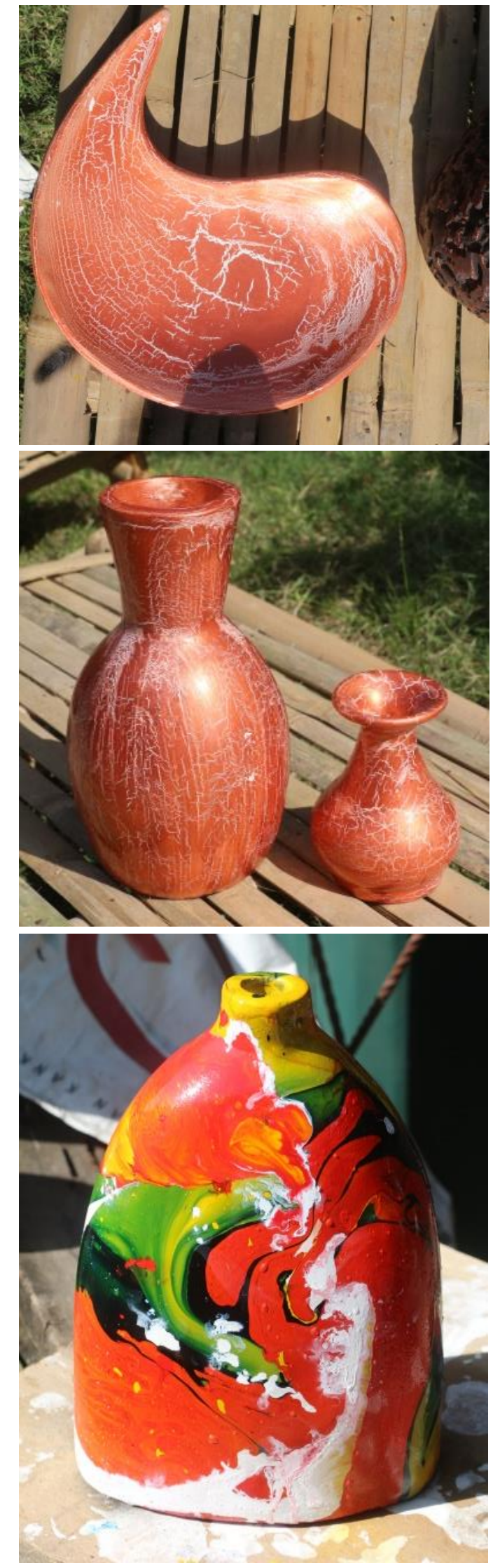



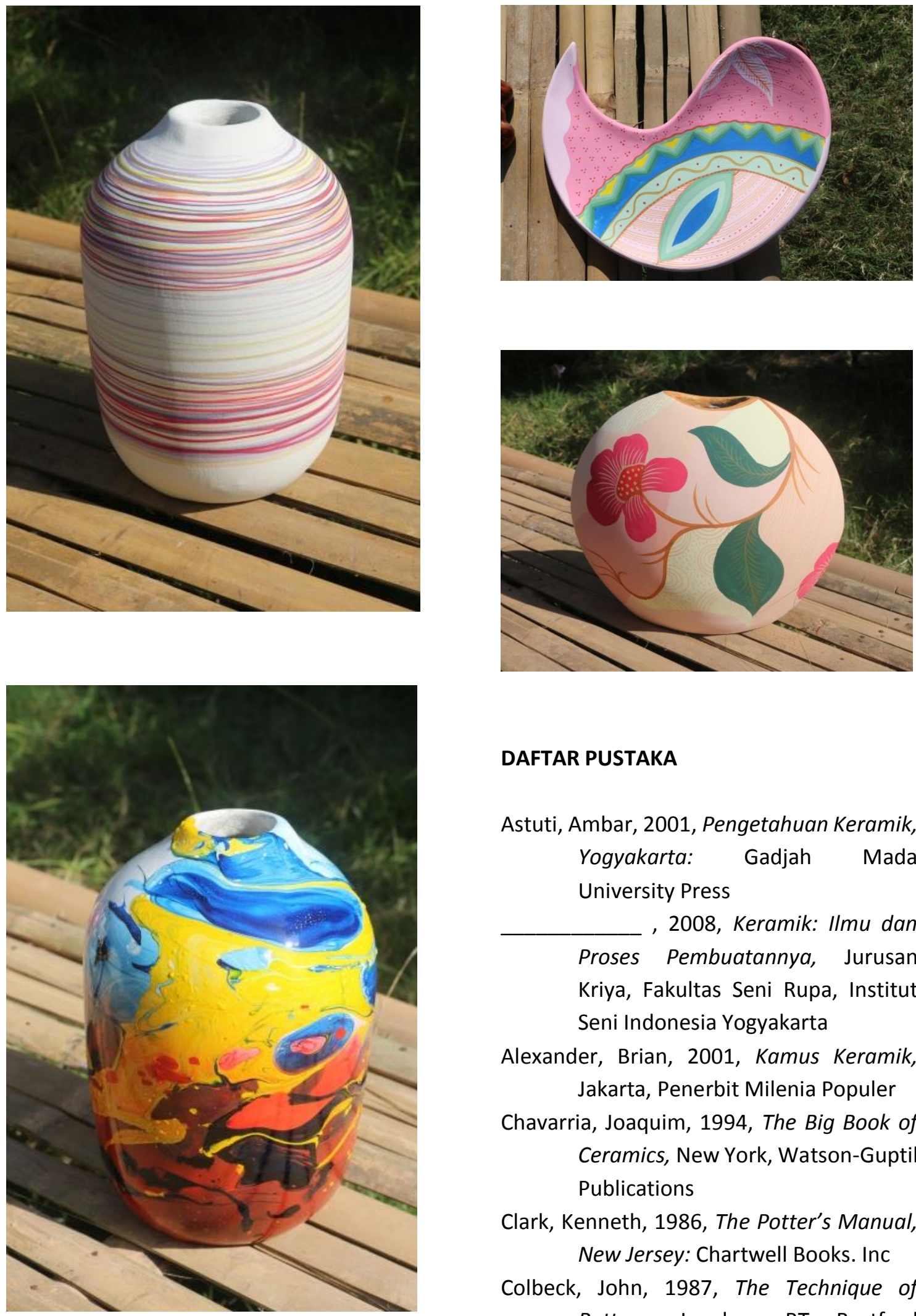

\section{DAFTAR PUSTAKA}

Astuti, Ambar, 2001, Pengetahuan Keramik, Yogyakarta: Gadjah Mada University Press , 2008, Keramik: Ilmu dan

Proses Pembuatannya, Jurusan Kriya, Fakultas Seni Rupa, Institut Seni Indonesia Yogyakarta

Alexander, Brian, 2001, Kamus Keramik, Jakarta, Penerbit Milenia Populer

Chavarria, Joaquim, 1994, The Big Book of Ceramics, New York, Watson-Guptil Publications

Clark, Kenneth, 1986, The Potter's Manual, New Jersey: Chartwell Books. Inc

Colbeck, John, 1987, The Technique of Pottery, London, BT Bestford Limited 
Daryono, Natas Setiabudi, 2001,

Pengenalan Keramik, Bandung,

Indy Label

Fischer, Joseph, 1994, The Folk Art of Java,

Oxford University Press, Oxford, Singapore, New York, Kualalumpur

Gustami, Saptoto, Narno S, 1985, Pola Hidup dan Produk Kerajinan Keramik Kasongan Yogyakarta, Departemen Pendidikan dan Kebudayaan Direktorat Jendral Kebudayaan Proyek Penelitian dan Pengkajian Kebudayaan Nusantara

Hogan, Elizabeth, 1977, Ceramic Techniques and Project, California Penerbit Lane Publishing CO, Menlo Park

Mucthar, But, 1991, "Daya Cipta Bidang Kriya" dalam SENI, Jurnal Pengetahuan dan Penciptaan Seni, VII/01, BP ISI Yogyakarta

Raharjo, Timbul, 2008, Seni Kerajinan Keramik Kasongan Yogyakarta Di Era Globalisasi: Perjalanan Dari Dusun Gerabah Menjadi Sentra Seni Kerajinan Keramik Yang Mendunia, (Disertasi), Universitas Gadjah Mada, Yogyakarta

R.A. Razak, 1981, Industri Keramik, Jakarta, Balai Pustaka

Yumarta, Yardini, 1981, Keramik, Bandung, Penerbit Angkasa 